\title{
Volatility of Socially Responsible Investments in Australia
}

\author{
Sophia X.N. Bian", John H. Fan ${ }^{\dagger}$ and Victor S. H. Wong ${ }^{\ddagger}$ \\ Socially responsible investment (SRI) has become \\ increasingly popular in recent years, as there is strong \\ evidence showing $S R I$ is less volatile and generates \\ higher returns than traditional investments. This paper \\ examines how volatility is spilled over from stocks and \\ bond markets into the Australian SRI market. We \\ employ TGARCH model from 1994 to 2015 and find \\ that the Australian SRI market is positively influenced \\ by domestic stock market. Furthermore, we find that \\ the Australian SRI market is less correlated with other \\ markets, hence, there is potential for diversification. \\ Our findings indicate performance persistence and \\ asymmetric effect in the volatilities of the Australian \\ SRI market.
}

JEL Classification: C32, G11, G15

\section{Introduction}

Since the awareness of corporate socially responsibility has risen tremendously during the last century, investors tend to incorporate this thinking process into their investments. Consequently, socially responsible investments (SRI) have become prevalent in the financial market (Boatright 2010; Renneboog et al 2008). SRI refers to the investment that considers social, environmental, ethical and financial dimensions all together. Given the nature of SRI, governments around the world, for example, the UK, Sweden, the US, France, Germany and South Africa, are trying to promote this socially beneficial investment by regulation (Berry et al 2011). The Australian government is also implementing this by increasing the level of disclosure on investment product ${ }^{1}$ and encouraging better communication between fund managers and clients ${ }^{2}$.

SRI is not a brand new investment class, the very first ethical fund could be traced back to 1928 (Renneboog et al 2008). Nowadays, the total US-domiciled assets under management using SRI strategies increased by $76 \%$ from $\$ 3.14$ trillion (2012) to $\$ 6.57$ trillion (2014) in just 2 years. The SRI universe has increased approximately tenfold since 1995 . The net asset under fund management incorporating ESG (environmental, social, and governmental) factors has soared from $\$ 202$ billion to $\$ 4,306$ billion from 2007 to 2014 (USSIF 2014). In the Australian market, responsible investment assets accounts for $50 \%$ of Australian's total asset under management, $\$ 629.5$ billion (RIAA 2015). The increasing popularity of SRI has attracted major investment management organisations, such as Capital Group and Wellington Asset Management to apply the ESG factors in their portfolios (USSIF 2014). Additionally, there is a tendency that the SRI is not only attractive to the socially concerned investors, the ordinary investors are becoming increasingly interested in this relatively new form of investment opportunity (Schlegelmilch 1997).

\footnotetext{
Department of Accounting, Finance and Economics, Griffith University, Australia. Email:

sophia.bian@griffithuni.edu.au

† Department of Accounting, Finance and Economics, Griffith University, Australia. Email: j.fan@griffith.edu.au

‡ Department of Accounting, Finance and Economics, Griffith University, Australia. Email: v.wong@griffith.edu.au (Corresponding author)
} 


\section{Bian, Fan \& Wong}

In the Australian market, the average SRI funds outperform the average Australian large-cap share funds and the ASX300 over the short, medium and long terms. Internationally, the SRI funds outperform the large-cap international share funds over the short and medium term but slightly underperform the large-cap international funds over the 10-year investment period. This is probably due to the fact that only limited data ( 2 funds) is collected for the long term SRI fund performance (RIAA 2015). The detailed comparison is shown in Appendix 1.

Additionally, from the observation of past performance, volatilities of the SRls are lower compared to the traditional investments and the returns are not compensated for the lower risk (see Bauer et al 2005, Bauer et al 2006; Bollen 2007; Halkos and Sepetis 2007; and Renneboog et al 2011). Therefore it is worthwhile to investigate the diversification benefits by investing into SRIs.

According to the modern portfolio theory (Markowitz 1952), an effective way to reduce risk while maintaining the same return is to diversify investments into different asset classes. A long history of investors diversifying their stock investments into the bond markets has been observed. With the rapid development of SRI, SRI market has widened investors' choices. J.P. Morgan published a report on the 'Impact Investments: An emerging asset class' on 29 November 2010 and Mercer published 'Investing in a time of climate change' in June 2015. Both reports stressed the importance of social responsibility issues regarding to the investment, which sheds light on the future SRI investment opportunities.

As mentioned previously, Australian SRI market accounts for $\$ 629.5$ billion in 2015 . With an increasing amount of new SRI-related investment products, the SRI market has experienced tremendous growth from year to year (RIAA 2015). Studies on SRI have not provided a complete analysis. The literature mainly focused on the return aspect and the volatility of SRI is still not well understood. To provide a more complete analysis of the risk and return characteristics, the objective of this paper is to identify the volatility pattern of the Australian $\mathrm{SRI}$ and the benefits of investing in SRIs for Australian portfolio managers. Recent market events indicate that crisis and extreme market shocks are becoming increasingly frequent. Thus, it is essential to understand how SRI investments might be impacted during market stress and whether SRI would provide avenues for diversification. Using TGARCH model, our study extends the SRI literature by capturing the volatility and spillover effect between Australian SRI markets with stocks and bonds markets both domestically and internationally. Our findings are in line with Nofsinger and Varma (2014) whereby SRI markets provide potential diversification benefits.

This paper is organised as follows, section 2 reviews the related literature on SRI and TGARCH model, sections 3 and 4 state the data and methodology employed in this paper. Section 5 discusses the results and section 6 concludes the paper.

\section{Brief Review of Literature}

\subsection{SRI Performance}

The sharp increase of SRI has caught the attention from academia, and many studies have been carried out to better understand these investment opportunities. Some studies present that sinful stocks perform better than the broad stock market (Ali and Gold 2002; Chong et al 2006), however others state that there is no statistically significant performance difference between SRI and broad stock markets. Bauer et al (2007), Hamilton et al (1993), Statman (2000) find there is no statistically significant difference between the SRI and the common stock funds' performance. Becchetti and Ciciretti (2009) and Luther and Matatko (1994) find 


\section{Bian, Fan \& Wong}

the same result at the index level. Sauer (1997) compares both the fund level and index level, and find statistically insignificant difference between them. Nofsinger and Varma (2014) find that during the crisis period, SRI funds outperform the conventional funds.

Socially responsible companies tend to disclose more information and experience fewer scandals which make their stock prices less volatile. Additionally, SRI investors prefer to put their money into stocks which they are familiar with (Merton 2012), making SRI a good candidate for their investment. This information disclosure advantage together with the preference of investors (Heinkel et al 2001) leads to an excess demand of SRI, which ultimately results in the mispricing of the SRI (Galema et al 2008). Furthermore, given that the $\mathrm{SRI}$ is booming in recent years, there may be a learning process for the SRI managers to fully understand the market and make a profit out of it (Bauer et al 2005, Bauer et al 2006). Due to the catch-up phase phenomenon, further studies are warranted using extended data sets.

\subsection{Threshold GARCH}

The movements of financial markets in recent years are characterised by high volatilities during periods of financial crises. Previous studies have found clustering effects, where high volatilities periods are often followed by high volatilities, and low volatilities periods are followed by low volatilities (see Bollerslev et al 1992; Lux and Marchesi 2000 and Cont 2005). In order to cope with the time-varying volatility, Engle (1982) introduces the autoregressive conditional heteroskedasticity $(\mathrm{ARCH})$ model. Unlike the traditional econometrics, the ARCH model does not assume one-period constant variance. Nonetheless, in the empirical application of the ARCH model, problems are raised from the fixed number of lags especially when there is a small number of data available. In 1986, Bollerslev develops the generalized autoregressive conditional heteroskedasticity $(\mathrm{GARCH})$. The formulation of $\mathrm{ARCH}$ and GARCH models are based on the magnitude of the lagged residuals not their signs, which gives the same weights to the positive and negative shocks (Halkos and Sepetis 2007). However, both the developed (Koutmos 1998) and the emerging stock markets (Pan 2010; Yavan and Aybar 1998) exhibit asymmetric volatility distribution. Nelson (1991) states that in the U.S. stock market, almost all the high volatilities are associated with the market downturn.

Furthermore, Henry (1998) reports the asymmetric effect in the Hong Kong stock market during January 1990 to June 1995, which means the symmetric GARCH model would underestimate the volatility for negative shocks and overestimate the volatility for positive shocks. Sentana (1995) also confirms the fact that an asymmetric GARCH model is better than the symmetric GARCH model in describing the stock market returns by using daily U.S. stock market returns and monthly U.K. stock market excess returns. As one of the first paper on TGARCH model, Zakoian (1994) found the asymmetric volatility effect in French stock market by using the daily French CAC stock index data for the period from January 1976 to July 1990. In addition, Australian stock market also exhibits strong asymmetric effect (Kearns and Pagan 1993; Mian and Adam 2001; Frijns et al 2010). The asymmetric effect can be captured by Exponential GARCH (Nelson 1991) and Threshold GARCH (Zakoian 1994). EGARCH has been criticised by Halkos and Sepetis (2007) due to its fixed relationship of different volatilities generated by positive and negative values. For the purpose of this study, the TGARCH model is the best to apply.

TGARCH has been applied to forecast the volatility in the financial market (see Bali 2000; McMillan and Speight 2004), and evaluate various financial markets (see Hughes et al 2007; $\mathrm{Lu}$ et al 2014; Nan et al 2010). Furthermore, TGARCH models are also widely used to examine spill over effect between different markets (Chan-Lau and Ivaschenko 2003; Cheung 


\section{Bian, Fan \& Wong}

et al 2010; Ellis and Lewis 2000; Gerlach et al. 2006) and also to study the return volatility response to good and bad news (Shamsuddin 2014).

Compared to traditional investments such as stocks and bonds, only a limited number of studies focus on the SRI market, especially on the risk and return characteristics. Thus, it is important to apply the suitable model on an extended SRI dataset. Most of the SRI studies apply the basic Sharpe ratio, Jensen's alpha, and the raw return and volatility to measure the SRI market movements. Only a few studies have employed the ARCH-type models but none applied on SRI market (see Chong et al 2006; Mill 2006; Becchetti et al 2007; Becchetti and Ciciretti 2009). This paper extends the literature by employing TGARCH model to examine the asymmetric effect and volatility spillover effect on Australian SRI markets domestically and internationally with stock and bond markets.

To the best knowledge of the authors, previous studies have not addressed the issue on how Australian SRI market are influenced by other markets. The majority of the studies focus on the returns aspect, very little research attention is devoted to understanding the risk aspect. To benefit SRI investors and fund managers, this study provides a robust analysis using TGARCH model within a recent sample period incorporating various financial crises and capturing volatility spillover effects in our results.

\section{Data}

Data used in this paper covers period from 3 January 1994 to 31 December 2015, which is equivalent to 22 years with 5,739 observations. The sample period is chosen based on the availability of SRI data. This sample period is rich with financial crises including the Asian Financial Crisis (1997), bursting of dot com bubble (2000), September 11 terrorist attacks (2001), Enron fraud scandal (2001), Iraq war (2003), Sub-prime housing crisis (2007-2009), the Ponzi scheme of Bernard Mandoff (2008), European debt crisis and Greek governmentdebt crisis (2009), Russian financial crisis (2014), Chinese stock market slow down and oil price slump (2015).

In order to achieve the purpose of comparison and diversification, six markets ${ }^{3}$ are analysed in this paper. S\&P/ASX200 ${ }^{4}$ STOCK $_{\text {AU }}$ ) and MSCI World ex Australia Index ${ }^{5}$ (STOCK WORLD ) are chosen as the Australian and international stock market benchmark. As for the bond market, the Australian $\left(\mathrm{BOND}_{\mathrm{AU}}\right)$ and the international $\left(B O N D_{\text {WORLD }}\right)$ indexes provided by J.P. Morgan ${ }^{6}$ are used. Dow Jones Sustainability Indexes ${ }^{7}$ (DJSI) for Australia (SRI $I_{A U}$ ) and excluding Australia (SRI WORLD) are applied as the SRI benchmark for Australian and the world.

Moreover the application of daily data provides a more concise description of the volatility regards to the period after financial crisis. Additionally, the daily frequency is essential to test the co-movement in different markets as investors change their asset allocation rapidly (Kim, Moshirian and Wu 2006). Notably the data cited in this paper are the returns calculated by the continuous returns formula $r_{t}=\ln \left(\right.$ price $_{t} /$ price $\left._{t-1}\right) \times 100 \%$.

\section{Methodology}

\subsection{Diagnostic Tests}

From the visual inspection of Figure 1, returns fluctuated around zero and the volatility of each market index is not constant over the observed period for all the indexes examined. Moreover, the fluctuation tends to be clustered together which is a strong indication of the ARCH effect. 


\section{Bian, Fan \& Wong}

Prior to estimating TGARCH model, unit roots and ARCH-LM tests have been performed on the data to ensure data is stationary and consist of $\mathrm{ARCH}$ effect.

\section{Figure 1: Daily Return Movements}
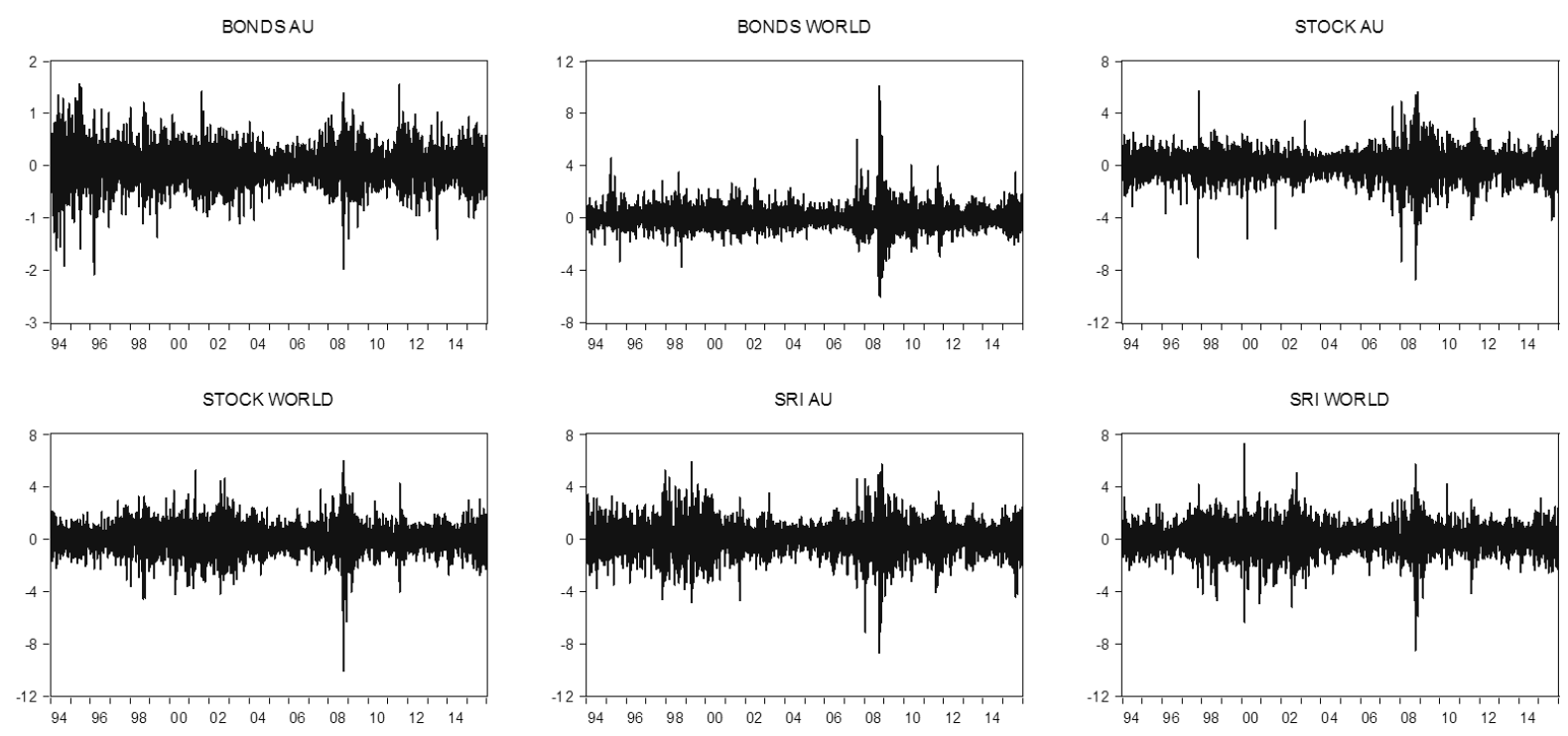

\subsection{Threshold GARCH Model}

As stated in the objective, the paper examines the volatility pattern of the Australian SRI market. The TGARCH model is specified with $\mathrm{SRI}_{\mathrm{AU}}$ as the dependent variable and SRI WORLD, BONDS $_{A U}, B O N D S_{W O R L D}, S_{\text {STOCKS }}$, and STOCKS WORLD $_{\text {as }}$ the independent variables. The volatility equation of Australian SRI market is estimated by regressing against the news shocks and its own past volatilities. There are two equations generated from GARCH model, one mean equation (Equation 1) and one variance equation (Equation 2). The conditional variance is not only regressed against the past sample variance, but also the lagged conditional variances.

$$
\begin{array}{cc}
Y_{t}=X_{t}^{\prime} \theta+\varepsilon_{t} & \text { Equation 1 } \\
\sigma_{t}^{2}=\omega+\alpha \epsilon_{t-1}^{2}+\beta \sigma_{t-1}^{2} & \text { Equation 2 }
\end{array}
$$

The TGARCH is developed from $\mathrm{GARCH}$ via an additional parameter $\gamma$, and equation for the conditional variance is given by:

$$
\sigma_{t}^{2}=\omega+\sum_{i=1}^{p} \alpha_{i} \epsilon_{t-1}^{2}+\sum_{j=1}^{q} \beta_{j} \sigma_{t-j}^{2}+\sum_{k=1}^{r} \gamma_{k} \epsilon_{t-1}^{2} I_{t-k}
$$

Equation 3

Where $I_{t}=1$ if $\epsilon_{t}<0$ and 0 otherwise.

In the application of TGARCH model, good news gives a positive $\epsilon_{t-1}$, which only affect the $\alpha_{i}$. While the bad news produces a negative $\epsilon_{t-1}$, that has an impact on both of the $\alpha_{i}$ and the $\gamma_{i}$. Therefore, bad news has higher volatility than good ones (Bouchaud et al 2001).

The TGARCH model provides improved estimates compared to previous ARCH and GARCH models, as Halkos and Sepetis (2007) pointed out that positive and negative movements in the 


\section{Bian, Fan \& Wong}

markets are not symmetrical and an asymmetric model is required to capture the asymmetric effect. Nelson (1991) confirms the volatilities are higher during market downturn. Hence, an asymmetric model such as TGARCH would provide a robust analysis of Australian SRI market volatilities during the good and the bad times.

\section{Empirical Results}

\subsection{Descriptive Statistics}

Table 1 presents the descriptive statistics. The highest mean return corresponds to

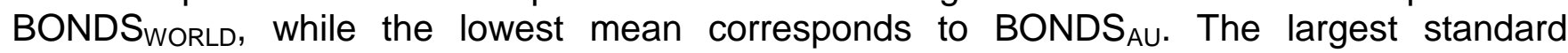
deviation is observed in the $\mathrm{SRI}_{\mathrm{AU}}$ whereas BONDS $\mathrm{SU}_{\mathrm{A}}$ exhibited the lowest standard deviation.

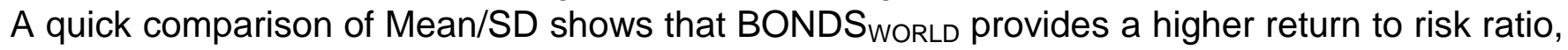
followed by STOCKS WORLD. BONDS $_{\text {WORLD }}$ would be the obvious best candidate to include into a portfolio since it has the highest return with lowest risk. Additionally, $\mathrm{SRI}_{\mathrm{AU}}$ and $\mathrm{SRI} \mathrm{IORLD}_{\mathrm{W}}$ provide positive return to risk ratios, however this requires further investigation on how SRI affects the overall investment performance for an investor.

Skewness indicates that all other time series are negatively skewed except for BOND wORLD. Kurtosis reveals that all the time series are leptokurtic with BONDWORLD being the most leptokurtic and $\mathrm{BOND}_{\mathrm{AU}}$ the least. This non-normal distribution is further confirmed by the $p$ values of Jarque-Bera tests. All the $p$-values are 0 which rejected the normal distribution assumption. Additionally the non-normal fat tailed distributions are consistent with what have been found by Müller et al (1998). The fat tail is also an indication of crashes happening more frequently than the forecast from normal distribution (Blanchard and Watson 1983). The high frequency of crashes occurred shed lights on the importance of controlling risk especially for investors who are new to SRI. It is important to point out that past literature on SRI have focused mainly on the return aspect and found mixed results (see Hamilton et al 1993, Statman 2000; Ali and Gold 2002; Chong et al 2006; Bauer et al 2007). As discussed previously, this study provides a robust analysis and creates a better understanding on how volatilities are spilled over between SRI markets, stock and bond markets domestically and internationally.

Table 1: Summary statistics on Index Returns

\begin{tabular}{lrrrrrr}
\hline & $\begin{array}{r}\text { SRI } \\
\text { AU }\end{array}$ & $\begin{array}{r}\text { SRI } \\
\text { WORLD }\end{array}$ & $\begin{array}{r}\text { BONDS } \\
\text { AU }\end{array}$ & $\begin{array}{r}\text { BONDS } \\
\text { WORLD }\end{array}$ & $\begin{array}{r}\text { STOCKS } \\
\text { AU }\end{array}$ & $\begin{array}{r}\text { STOCKS } \\
\text { WORLD }\end{array}$ \\
\hline Mean & 0.0116 & 0.0158 & -0.0006 & 0.0171 & 0.0160 & 0.0166 \\
Std. Dev. & 1.1114 & 0.9888 & 0.3139 & 0.7581 & 0.9616 & 0.9708 \\
Mean/SD & 0.0105 & 0.0160 & -0.0019 & 0.0225 & 0.0166 & 0.0171 \\
Skewness & -0.1480 & -0.2820 & -0.1766 & 1.1561 & -0.4618 & -0.3434 \\
Kurtosis & 6.4641 & 7.0311 & 5.7617 & 20.3754 & 8.8688 & 7.9090 \\
J-Bera & 2890 & 3962 & 1854 & 73471 & 8440 & 5875 \\
\hline
\end{tabular}




\section{Bian, Fan \& Wong}

Table 2: Correlations between Indexes

\begin{tabular}{lrrrrrr}
\hline & $\begin{array}{r}\text { SRI } \\
\text { AU }\end{array}$ & $\begin{array}{r}\text { SRI } \\
\text { WORLD }\end{array}$ & $\begin{array}{r}\text { BONDS } \\
\text { AU }\end{array}$ & $\begin{array}{r}\text { BONDS } \\
\text { WORLD }\end{array}$ & $\begin{array}{r}\text { STOCKS } \\
\text { AU }\end{array}$ & $\begin{array}{r}\text { STOCKS } \\
\text { WORLD }\end{array}$ \\
\hline SRI $_{\text {AU }}$ & 1.0000 & & & & & \\
SRI $_{\text {WORLD }}$ & 0.1418 & 1.0000 & & & & \\
BONDS $_{\text {AU }}$ & -0.1417 & 0.0138 & 1.0000 & & & \\
BONDS $_{\text {WORLD }}$ & -0.2903 & 0.1408 & 0.2615 & 1.0000 & & \\
STOCK $_{\text {AU }}$ & 0.8716 & 0.1753 & -0.1451 & -0.3004 & 1.0000 & \\
STOCK $_{\text {WORLD }}$ & 0.0722 & 0.8935 & 0.0362 & 0.2768 & 0.1006 & 1.0000 \\
\hline
\end{tabular}

For the purpose of maximising profit and minimising risk, investors should not only consider return and risk, correlations play an important role in asset selection. Correlations between each asset are shown in Table 2. As this paper adopts the Australian investor's perspective, the main focus of discussion will be on the correlation of $\mathrm{SRI}_{\mathrm{AU}}$ with other markets. The highest correlation to $\mathrm{SRI}_{\mathrm{AU}}$ is the $\mathrm{STOCK}_{\mathrm{AU}}(0.8716)$. The high correlation implying that these two share markets have a fairly high chance of moving in the same direction, i.e. one market is going down, another market will follow to go down significantly. Furthermore $\mathrm{SRI}_{\mathrm{AU}}$ is also positively correlated with SRI WORLD $_{\text {and STOCK }}$ WORLD. However the degree of correlation are considered moderate, which are only 0.1418 and 0.0722 , respectively. The negative correlations between $\mathrm{SRI}_{\mathrm{AU}}$ and $\mathrm{BOND}_{\mathrm{AU}}(-0.1417)$ and $\mathrm{BOND}$ WORLD $(-0.2903 \%)$ suggest that the $\mathrm{SRI}_{\mathrm{AU}}$ is moving in an opposite direction with these two markets. These different movements between $S R I_{A U}$ and bond markets might provide investors with the opportunity for diversification.

\subsection{Results of Diagnostic Tests}

Unit root tests, such as Augmented Dickey-Fuller (ADF) and Phillip Perron (PP) are performed on the returns data including trend and intercept to examine the stationarity. As shown in Table 3 , the unit root hypotheses are rejected. This means that all the variables are stationary at level terms. Furthermore, results from ARCH Lagrange multiplier (LM) test confirms the existence of heteroskedasticity within the data. We also conduct diagnostic tests on other asymmetric GARCH models, such as GJR-GARCH, EGARCH, GARCH-in-mean and found that the TGARCH model provides the best fit to the data. The existence of ARCH effect in SRI markets is consistent with Tularam et al (2010).

Table 3: Results of Unit Root Tests

\begin{tabular}{lrrrrrr}
\hline & $\begin{array}{r}\text { BONDS } \\
\text { AU }\end{array}$ & $\begin{array}{r}\text { BONDS } \\
\text { WORLD }\end{array}$ & $\begin{array}{r}\text { STOCKS } \\
\text { AU }\end{array}$ & $\begin{array}{r}\text { STOCKS } \\
\text { WORLD }\end{array}$ & $\begin{array}{r}\text { SRI } \\
\text { AU }\end{array}$ & $\begin{array}{r}\text { SRI } \\
\text { WORLD }\end{array}$ \\
\hline ADF & -79.694 & -75.578 & -77.058 & -79.362 & -73.803 & -46.996 \\
PP & -80.000 & -75.749 & -77.338 & -80.128 & -73.928 & -76.159 \\
LM (1) & 39.441 & 199.886 & 404.048 & 278.614 & 283.691 & 189.484 \\
LM (5) & 208.827 & $1,142.601$ & 950.900 & 849.132 & 891.274 & 522.276 \\
LM (10) & 270.802 & $1,241.319$ & $1,117.616$ & $1,058.939$ & $1,017.951$ & 667.087 \\
\hline
\end{tabular}

\subsection{Results from Threshold GARCH Model}

To understand relationship between Australian SRI and other markets, TGARCH $(1,1,1)^{8}$ is employed and estimation results are shown in Table 4. Even though there are 5 independent variables and one intercept term for the regression, only 1 of them is significant. The STOCK $A U$ is significant at $1 \%$ levels. It is obvious that Australian SRI and STOCKS are related closely to 


\section{Bian, Fan \& Wong}

each other, the positive coefficient value for the STOCKS $\mathrm{AU}_{\mathrm{U}}$ is relatively high at 1.0052, which imply that movements in STOCKS $S_{A U}$ would also cause movements in $S R I_{A U}$. The insignificant return relationship of $S R I_{A U}$ with other variables (except with $S T O C K S_{A U}$ ) implies that $S R I_{A U}$ market is not influenced by movements in other markets such as STOCKS and BONDS both domestically and internationally.

Table 4: TGARCH Model Estimation Output

\begin{tabular}{|c|c|c|c|}
\hline & Coefficient & Standard Error & P-value \\
\hline \multicolumn{4}{|c|}{ Panel A: Mean Equation } \\
\hline $\mathrm{C}$ & -0.0029 & 0.0021 & 0.1678 \\
\hline SRI $I_{\text {WORLD }}$ & -0.0023 & 0.0072 & 0.7442 \\
\hline BONDS $_{A U}$ & 0.0093 & 0.0079 & 0.2386 \\
\hline BONDS ${ }_{W O R L D}$ & -0.0028 & 0.0033 & 0.3902 \\
\hline STOCKS $_{A U}$ & 1.0052 & 0.0022 & 0.0000 \\
\hline STOCKSWORLD & 0.0028 & 0.0073 & 0.6986 \\
\hline \multicolumn{4}{|c|}{ Panel B: Variance Equation } \\
\hline C & 0.0001 & 0.0000 & 0.0001 \\
\hline$\epsilon_{t-1}^{2}$ & 0.0505 & 0.0036 & 0.0000 \\
\hline$\epsilon_{t-1}^{2}\left(\epsilon_{t-1}<0\right)$ & 0.0016 & 0.0052 & 0.7570 \\
\hline$\sigma_{t-1}^{2}$ & 0.9495 & 0.0027 & 0.0000 \\
\hline
\end{tabular}

Notes to Table 4:

The mean equation is written as: $S R I_{A U}=-0.0029+-0.0023 S R I_{\text {WORLD }}+0.0093 B O N D S_{A U}+-0.0028 B O N D S_{W O R L D}$ +1.0052 STOCKS $S_{A U}+0.0028 S T O C K S_{W O R L D}$. The variance equation is expressed as: $\sigma_{t}^{2}=0.0001+0.0505 \epsilon_{t-1}^{2}+$ $0.0016 \epsilon_{t-1}^{2}\left(\epsilon_{t-1}<0\right)+0.9495 \sigma_{t-1}^{2}$

With regards to the conditional volatility regression equation shown in Panel B of Table 4, all of the coefficients are significant except for $\epsilon_{t-1}^{2}\left(\epsilon_{t-1}<0\right)$. The $p$-value and positive coefficient of $\epsilon_{t-1}^{2}$ imply the shocks from previous trading day has a significant positive impact on the current conditional variance. Both of the asymmetric terms are significant, indicating that $\mathrm{SRI}_{\mathrm{AU}}$ volatility respond to good and bad news differently and Australian SRI market need at least one lag or one day to absorb the bad news. The first lag coefficient of the asymmetric term is positive, suggesting that when bad news first hit the $\mathrm{SRI}_{\mathrm{AU}}$ market, Australian SRI investors' overreact to the bad news, and the volatility of SRI market increases. Consistent with previous studies in Australian stock market, our study confirms the asymmetric effect in the Australian SRI market (see Kearns and Pagan 1993; Mian and Adam 2001 and Frijns et al 2010).

The significant $\sigma_{t-1}^{2}$ coefficient implies a performance persistent effect in the $\mathrm{SRI}$ AU market, where high volatility period is followed by high volatility period, and low volatility period is followed by low volatility period. Further evidence can be found in Figures 2 and 3. Figure 2 shows the actual, fitted and residual lines. It can be seen that the model is a good fit since most of the time the fitted line is overlapping with the actual line. It also reveals that during the highly volatile periods, predictive power of the regression is weaker. This is further verified by Figure 3, when the conditional standard deviation is high, the regression residual is also high. In line with Bollerslev et al (1992); Lux and Marchesi (2000) and Cont (2005), our results confirm the existence of the volality clustering effect. 


\section{Bian, Fan \& Wong}

Figure 2: Residual, Actual and Fitted Lines

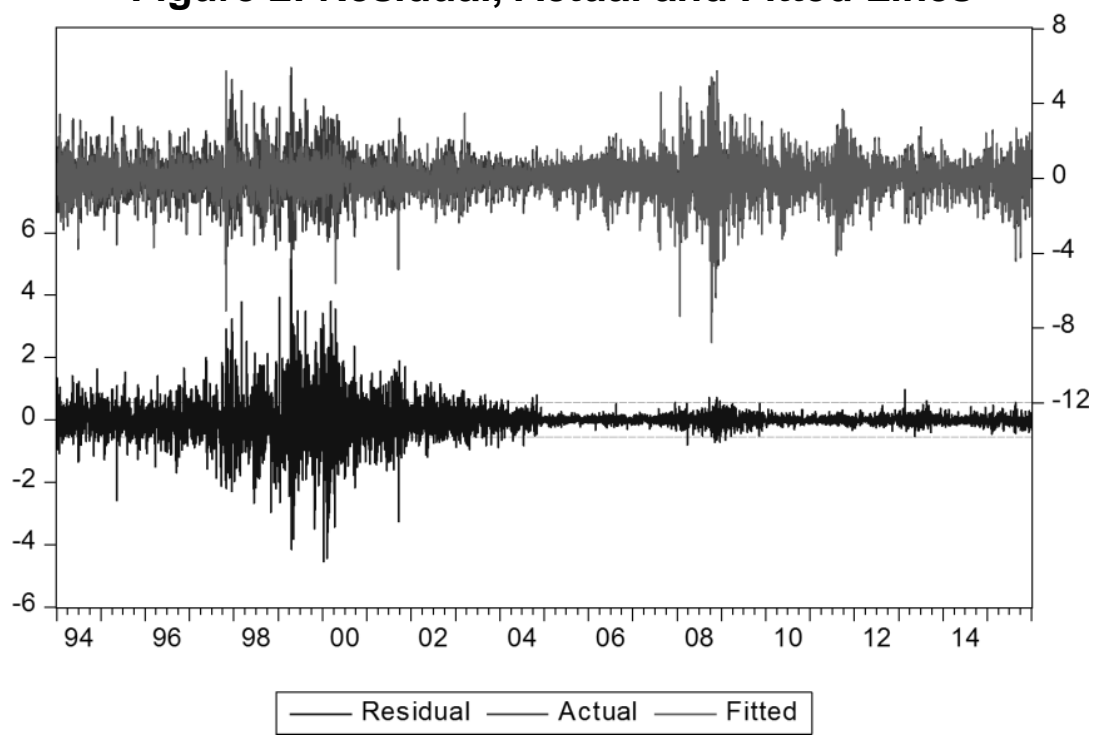

As shown in Figure 3, periods from 1997 to 2002 and from 2007 to 2009 are more volatile relatively. These two periods experienced most market extreme events across the entire sample period. The first volatile period covers the Asian Financial Crisis (1997), bursting of dot com bubble (2000), September 11 terrorist attack (2001) and Enron fraud scandal (2001). The sub-prime housing crisis (2007-2009) occurred in the second volatile period. Therefore, investment decisions formed solely based on normal expectation is insufficient. The market will become more volatile when shocks arrive, which severely diminishes the predictive power of regression. Furthermore, these financial crises are difficult to predict. To survive from these events, it is extremely important for investors to prepare for the potential financial crisis.

The results in Section 5.3 suggest that correlation between Australian SRI markets with stocks and bond markets are generally low. This implies that the Australian SRI market is insulated from all other market movements with the exception of the Australian stock market. Thus, the findings highlight the potential for diversification in the Australian SRI market, however further studies are warranted to investigate these benefits.

Figure 3: Conditional Standard Deviation

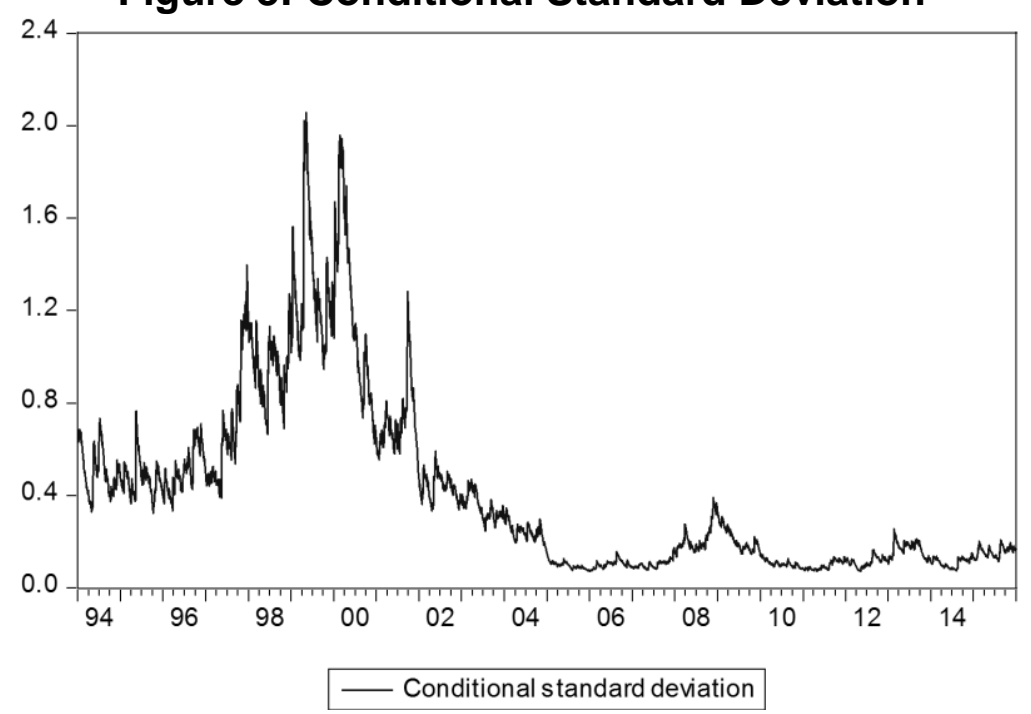




\section{Bian, Fan \& Wong}

\section{Conclusion}

The size of the SRI markets have increased dramatically over the past two decades. Investors are increasingly concerned with how SRI market interacts with stocks and bonds in their portfolio. Recent financial crises highlighted the urgency for investors to understand how volatility is spilled over from the stocks and bond markets into the Australian SRI market. The paper examined the volatility patterns between Australian SRI, stock and bond markets, both domestically and internationally.

This paper employed the TGARCH model to capture the performance persistence effect and the asymmetric effect within the Australian SRI market. The findings presented in this paper suggest that TGARCH $(1,1,1)$ is the most suitable model for the data employed in the study. The results support the findings from Tularam, Roca, and Wong (2010) that there is ARCH effect in the SRI markets. Furthermore, we find the Australian SRI market's volatility reacts differently to the good and bad news. Our findings on asymmetric volatilities are consistent with previous studies by Nelson (1991), Kearns and Pagan (1993), Zakoian (1994), Sentana (1995), Henry (1998), Koutmos (1998), Yavan and Aybar (1998), Mian and Adam (2001), Frijns et al (2010) and Pan (2010).

The estimated parameters of the return regression reveal that the Australian SRI market is influenced positively by the Australian stock market. For an Australian investor, the results imply that investing in other markets would provide diversification benefits due to the lower correlations among these markets. Furthermore, we demonstrated the existence of volatility clustering effect in the Australian SRI market. The findings reveal a delay of one trading day for the Australian SRI market to fully absorb the bad news.

The findings presented in this paper provide important implications for the academics as well as the market participants. The results provide a deeper understanding of SRI volatility spillover effects and our findings reveal that SRI has potential for diversification benefits. Equipped with a better understanding of the volatility spillover effect, investors and fund managers are able to better manage their portfolio allocation into the Australian SRI markets. Regulators should develop appropriate policies for financial products to limit the down-side risk exposure of the SRI.

\section{Endnotes}

\footnotetext{
${ }^{1}$ Financial Service Reform Act 2001 and compulsory guidelines from Australian Securities and Investment Commission.

${ }^{2}$ Best Practice Guidelines from Australian Securities and Investment Commission since May 2005.

${ }^{3}$ To keep the study away from the confounding context of portfolio management, for example, the transaction cost, management fees, management skills, market timing and different investment policies, only the index values are used to do the analysis. In this way, only the potential opportunity to diversify into SRI market is tested.

${ }^{4}$ S\&P/ASX200 composed of S\&P/ASX100 and an additional 100 stocks (Australian Securities Exchange 2015). It is commonly used as an Australian stock market benchmark due to the fact that stocks are highly liquid and it covers approximately 80\% Australian equity market capitalization (S\&P Dow Jones Indices 2015).

${ }^{5} \mathrm{MSCl}$ World ex Australia Index represents the stock market movements from the 23 most developed markets (excluding the Australian market) aggregately. It consists of 1,556 stocks that are relatively large in terms of the market capitalization. Due to the broad coverage from a global perspective, the MSCI World Index is suitable to be an international benchmark index (MSCI 2015).

${ }^{6}$ The J.P. Morgan Government Bond Index, first launched in 1989, represents the bond performance from highincome countries all around the world that consist of Australia, Belgium, Canada, Denmark, France, Germany, Italy, Japan, Netherlands, Spain, Sweden, United Kingdom and United States (J.P. Morgan 2015). In addition, the J.P. Morgan Government Bond Index has become the most widely used benchmark to measure the risk-
} 


\section{Bian, Fan \& Wong}

return relationship internationally (Trade2Win 2015). Following Erb et al (1994) and Kritzman and Page (2003), J.P. Morgan government bond indexes are used in this study.

${ }^{7}$ The DJSI first launched in 8 September 1999 and became the very first socially responsible index. The DJSI only tracks the performance from the top $10 \%$ companies in terms of the sustainability performance captured by the best-in-class approach from the 2,500 largest companies in the Dow Jones Global Total Stock Market Index (Dow Jones Sustainability Indexes 2015).

${ }^{8}$ Different sets of model specification parameters are compared and TGARCH $(1,1,1)$ is chosen based on the SIC values. Results are not shown here, however, they are available upon request.

\section{References}

Ali, PU \& Gold, M 2002, 'An appraisal of socially responsible investments and implications for trustees and other investment fiduciaries', University of Melbourne: Centre for Corporate Law and Securities Regulation.

Australian Securities Exchange 2015, 'S\&P/ASX 200 Index Capitalisation indices', viewed 30 January $\quad 2016 \quad<$ http://www.asx.com.au/products/capitalisationindices.htm\#sp_asx_200_index>

Bali, TG 2000, 'Testing the empirical performance of stochastic volatility models of the shortterm interest rate', Journal of Financial and Quantitative Analysis, vol. 35, no. 2, pp. 191216.

Bauer, R, Derwall, J \& Otten, R 2007, 'The ethical mutual fund performance debate: New evidence from Canada', Journal of Business Ethics, vol. 70, no. 2, pp. 111-24.

Bauer, R, Koedijk, K \& Otten, R 2005, 'International evidence on ethical mutual fund performance and investment style', Journal of Banking and Finance, vol. 29, no. 7, pp. 1751-67.

Bauer, R, Otten, R \& Tourani Rad, A 2006, 'Ethical investing in Australia: Is there a financial penalty?', Pacific-Basin Finance Journal, vol. 14, no. 1, pp. 33-48.

Becchetti, L \& Ciciretti, R 2009, 'Corporate social responsibility and stock market performance', Applied Financial Economics, vol. 19, no. 16, pp. 1283-93.

Becchetti, L, Ciciretti, R \& Hasan, I 2007, 'Corporate social responsibility and shareholder's value: An event study analysis', Federal Reserve Bank of Atlanta.

Berry, T, Edgerton, N \& George, A 2011, 'Mainstreaming Socially Responsible Investment (SRI): A role for government? Policy recommendation from the investment community', University of Technology, viewed 20 September 2015, <http://www.isf.uts.edu.au/pdfs/srireport181105.pdf>.

Blanchard, OJ \& Watson, MW 1983, 'Bubbles, rational expectations and financial markets', National Bureau of Economic Research Cambridge, Mass., USA.

Boatright, JR 2010, 'Finance Ethics: Critical Issues in Theory and Practice', 1st edn, John Wiley and Sons, U.S.

Bollen, NPB 2007, 'Mutual fund attributes and investor behavior', Journal of Financial and Quantitative Analysis, vol. 42, no. 3, pp. 683-708.

Bollerslev, T 1986, 'Generalized autoregressive conditional heteroskedasticity', Journal of Econometrics, vol. 31, no. 3, pp. 307-27.

Bollerslev, T, Chou, RY \& Kroner, KF 1992, 'ARCH modeling in finance: A review of the theory and empirical evidence', Journal of Econometrics, vol. 52, no. 1, pp. 5-59.

Bouchaud, JP, Matacz, A \& Potters, M 2001, 'Leverage effect in financial markets: The retarded volatility model', Physical Review Letters, vol. 87, no. 22, pp. 1-4.

Chan-Lau, JA \& Ivaschenko, I 2003, 'Asian Flu or Wall Street virus? Tech and non-tech spillovers in the United States and Asia', Journal of Multinational Financial Management, vol. 13, no. 4-5, pp. 303-22. 


\section{Bian, Fan \& Wong}

Cheung, W, Fung, S \& Tsai, SC 2010, 'Global capital market interdependence and spillover effect of credit risk: evidence from the 2007-2009 global financial crisis', Applied Financial Economics, vol. 20, no. 1-2, pp. 85-103.

Chong, J, Her, M \& Phillips, GM 2006, 'To sin or not to sin? Now that's the question', Journal of Asset Management, vol. 6, no. 6, pp. 406-17.

Cont, R, 2007, 'Volatility clustering in financial markets: Empirical facts and agent-based models', In Long memory in economics (pp. 289-309). Springer Berlin Heidelberg.

Dow Jones Sustainability Indexes 2015, 'Dow Jones Sustainability World Indexes Guide Book', $\begin{array}{llll}\text { viewed } & 2 & \text { November } & 2015,\end{array}$ sustainability-indexes.com/images/djsi-world-guidebook_tcm1071-337244.pdf>.

Ellis, $L$ and Lewis E, 2000, 'The response of financial markets in Australia and New Zealand to news about the Asian crisis', International Financial Markets And The Implications For Monetary And Financial Stability, vol. 8, p.308.

Engle, RF 1982, 'Autoregressive conditional heteroscedasticity with estimates of the variance of United Kingdom inflation', Econometrica: Journal of the Econometric Society, vol. 50, no. 4, pp. 987-1007.

Erb, CB, Harvey, CR \& Viskanta, TE 1994, 'National risk in global fixed-income allocation', Journal of Fixed Income, vol. 4, no. 2, pp. 17-26.

Frijns, B, Tallau, C \& Tourani Rad, A 2010, 'The information content of implied volatility: Evidence from Australia', Journal of Futures Markets, vol. 30, no. 2, pp. 134-55.

Galema, R, Plantinga, A \& Scholtens, B 2008, 'The stocks at stake: Return and risk in socially responsible investment', Journal of Banking and Finance, vol. 32, no. 12, pp. 2646-54.

Gerlach, R, Chen, CWS, Lin, DSY \& Huang, MH 2006, 'Asymmetric responses of international stock markets to trading volume', Physica A: Statistical Mechanics and its Applications, vol. 360, no. 2, pp. 422-44.

Halkos, G \& Sepetis, A 2007, 'Can capital markets respond to environmental policy of firms? Evidence from Greece', Ecological Economics, vol. 63, no. 2, pp. 578-87.

Hamilton, S, Jo, H \& Statman, M 1993, 'Doing Well While Doing Good? The Investment Performance of Socially Responsible Mutual Funds', Financial Analysts Journal, vol. 49, no. 6 , pp. 62-6.

Heinkel, R, Kraus, A \& Zechner, J 2001, 'The effect of green investment on corporate behavior', Journal of Financial and Quantitative Analysis, vol. 36, no. 4, pp. 431-50.

Henry, O 1998, 'Modelling the asymmetry of stock market volatility', Applied Financial Economics, vol. 8, no. 2, pp. 145-53.

Hughes, MP, Smith, SD \& Winters, DB 2007, 'An empirical examination of intraday volatility in on-the-run US Treasury bills', Journal of Economics and Business, vol. 59, no. 6, pp. 487-99.

J.P. Morgan 2010, 'Impact Investments: An emerging asset class' viewed 5 March 2015, <https://thegiin.org/assets/documents/Impact\%20Investments\%20an\%20Emerging\%20A sset\%20Class2.pdf>

J.P. Morgan 2015, 'Developed Markets Indices', viewed 11 August 2015, <http://www.jpmorgan.com/pages/jpmorgan/investbk/solutions/research/indices/product>.

Kearns, P \& Pagan, AR 1993, 'Australian Stock Market Volatility: 1875-1987', Economic Record, vol. 69, no. 2, pp. 163-78.

Kim, SJ, Moshirian, F \& Wu, E 2006, 'Evolution of international stock and bond market integration: Influence of the European Monetary Union', Journal of Banking and Finance, vol. 30 , no. 5 , pp. 1507-34.

Koutmos, G 1998, 'Asymmetries in the conditional mean and the conditional variance: Evidence from nine stock markets', Journal of Economics and Business, vol. 50, no. 3, pp. 277-90. 


\section{Bian, Fan \& Wong}

Kritzman, M \& Page, S 2003, 'The hierarchy of investment choice', Journal of Portfolio Management, vol. 29, no. 4, pp. 11-23.

Lu, XF, Lai, KK \& Liang, L 2014, 'Portfolio value-at-risk estimation in energy futures markets with time-varying copula-GARCH model', Annals of Operations Research, vol. 219, no. 1, pp. 333-57.

Luther, R \& Matatko, J 1994, 'The performance of ethical unit trusts: choosing an appropriate benchmark', British Accounting Review, vol. 26, no. 1, pp. 77-89.

Lux, T \& Marchesi, M 2000, 'Volatility clustering in financial markets: A microsimulation of interacting agents', International Journal of Theoretical and Applied Finance, vol. 3, no. 04, pp. 675-702.

Markowitz, H 1952, 'Portfolio selection', Journal of Finance, vol. 7, no. 1, pp. 77-91.

McMillan, DG \& Speight, AEH 2004, 'Daily volatility forecasts: reassessing the performance of GARCH models', Journal of Forecasting, vol. 23, no. 6, pp. 449-60.

Mercer 2015, 'Investing in a time of climate change', viewed 23 June 2015 $<$ http://www.mercer.com/services/investments/investment-opportunities/responsibleinvestment/investing-in-a-time-of-climate-change-report-2015.html>

Merton, RC 2012, 'A simple model of capital market equilibrium with incomplete information', Journal of Finance, vol. 42, no. 3, pp. 483-510.

Mian, GM \& Adam, CM 2001, 'Volatility dynamics in high frequency financial data: an empirical investigation of the Australian equity returns', Applied Financial Economics, vol. 11, no. 3, pp. 341-52.

Mill, GA 2006, 'The financial performance of a socially responsible investment over time and a possible link with corporate social responsibility', Journal of Business Ethics, vol. 63, no. 2, pp. 131-48.

MSCl 2015, 'MSCl World ex Australia Index', viewed 11 August 2015, $<$ http://www.msci.com/resources/factsheets/index_fact_sheet/msci-world-ex-australiaindex.pdf>.

Müller, UA, Dacorogna, MM \& Pictet, OV 1998, 'Heavy tails in high-frequency financial data', A Practical Guide to Heavy Tails: Statistical Techniques and Applications. Boston: Birkhaüser, pp. 55-77.

Nan, L, Hong, L \& Zheng, Q 2010, 'An empirical study on the existence of bubble in Chinese stock market: Based on TGARCH model', paper presented to Information and Financial Engineering (ICIFE).

Nelson, DB 1991, 'Conditional heteroskedasticity in asset returns: a new approach', Econometrica: Journal of the Econometric Society, vol. 59, no. 2, pp. 347-70.

Nofsinger, J \& Varma, A 2014, 'Socially responsible funds and market crises', Journal of Banking and Finance, vol. 48, pp. 180-93.

Pan, W 2010, 'Empirical analysis of stock returns volatility in China market based on Shanghai and Shenzhen 300 Index', in Financial Theory and Engineering (ICFTE), Nanchang, China, pp. 17-21.

Renneboog, L, Ter Horst, J \& Zhang, C 2008, 'Socially responsible investments: Institutional aspects, performance, and investor behavior', Journal of Banking and Finance, vol. 32, no. 9, pp. 1723-42.

Renneboog, L, Ter Horst, J \& Zhang, C 2011, 'Is ethical money financially smart?', Journal of Financial Intermediation, vol. 20, no. 4, pp. 562-88.

RIAA 2015, 'Responsible Investment Benchmark Report 2015 Australia', viewed 7 December 2015, $<$ http://responsibleinvestment.org/wp/content/uploads/2015/08/2015_ Benchmark Report Aust FINAL.pdf>.

S\&P Dow Jones Indices 2015, 'S\&P/ASX 200', viewed 11 August 2015, $<$ http://us.spindices.com/indices/equity/sp-asx-200>. 
Sauer, DA 1997, 'The impact of social-responsibility screens on investment performance: Evidence from the Domini 400 Social Index and Domini Equity Mutual Fund', Review of Financial Economics, vol. 6, no. 2, pp. 137-49.

Schlegelmilch, BB 1997, 'The relative importance of ethical and environmental screening: implications for the marketing of ethical investment funds', International Journal of Bank Marketing, vol. 15, no. 2, pp. 48-53.

Sentana, E 1995, 'Quadratic ARCH Models', Review of Economic Studies, vol. 62, no. 4, pp. $639-61$.

Shamsuddin, A 2014, 'Are Dow Jones Islamic equity indices exposed to interest rate risk?', Economic Modelling, vol. 39, pp. 273-81.

Statman, M 2000, 'Socially responsible mutual funds', Financial Analysts Journal, vol. 56, no. 3, pp. 30-9.

Trade2Win 2015, 'J.P. Morgan Government Bond Index', viewed 11 August 2015, <http://www.trade2win.com/traderpedia/J.P._Morgan_Government_Bond_Index>.

Tularam, GA, Roca, ED \& Wong, V 2010, 'Investigation of socially responsible investment markets (SRI) using dynamic conditional correlation (DCC) method: Implications for diversification', Journal of Mathematics and Statistics, vol. 6, no. 4, pp. 385-394.

USSIF 2014, 'Report on US Sustainable, Responsible and Imapct Investing Trends', viewed 8 September $2015<$ http://www.ussif.org/Files/Publications/SIF_Trends_14.F.ES.pdf>.

Yavan, ZA \& Aybar, CB 1998, 'Volatility in Istanbul Stock Exchange', ISE Review, vol. 6, no. 2, pp. 35-47.

Zakoian, JM 1994, 'Threshold heteroskedastic models', Journal of Economic Dynamics and Control, vol. 18, no. 5, pp. 931-55. 


\section{Bian, Fan \& Wong}

\section{Appendix}

Appendix 1: Comparison between SRI and Mainstream Share Funds

\begin{tabular}{lcccc}
\hline & $\mathbf{1}$ year & $\mathbf{3}$ years & $\mathbf{5}$ years & $\mathbf{1 0}$ years \\
\hline Australian Stock Funds & & & & \\
\hline Average SRI Fund & $6.9 \%$ & $17.6 \%$ & $8.0 \%$ & $8.1 \%$ \\
Average Mainstream Fund & $4.3 \%$ & $14.2 \%$ & $5.8 \%$ & $6.8 \%$ \\
S\&P/ASX 300 Accumulation & $5.3 \%$ & $14.7 \%$ & $6.5 \%$ & $7.4 \%$ \\
\hline Overseas Stock Funds & & & \\
\hline Average SRI Fund & $15.5 \%$ & $24.7 \%$ & $11.7 \%$ & $4.2 \%$ \\
Average Mainstream Fund & $12.5 \%$ & $22.9 \%$ & $11.1 \%$ & $4.9 \%$ \\
MSCI World ex Australia Index & $15.0 \%$ & $24.8 \%$ & $12.5 \%$ & $5.5 \%$ \\
Balanced Growth Funds & & & & \\
\hline Average SRI Fund & $10.9 \%$ & $13.9 \%$ & $7.6 \%$ & $7.7 \%$ \\
Average Mainstream Fund & $7.8 \%$ & $12.9 \%$ & $7.2 \%$ & $5.6 \%$ \\
\hline
\end{tabular}

Table 1 extracted from the Responsible Investment Annual 2015 Report (RIAA 2015). 